\title{
Natural radionuclides from coal fired thermal power plants - estimation of atmospheric release and inhalation risk
}

\author{
G.G. Pandit, S.K. Sahu and V.D. Puranik \\ Environmental Assessment Division, Bhabha Atomic Research Centre, Trombay, \\ Mumbai-400085, India \\ e-mail: ggp@barc.gov.in
}

\begin{abstract}
Coal, bottom ash and fly ash samples were collected from three different coal-fired thermal power plants in India and subjected to gamma spectrometry analysis for natural radioactivity contents. The results of present study show that fly ash and bottom ash contains two to five times more natural radionuclides than feed coal. None of the fly-ash and bottom ash samples had radium equivalent activities and external hazard index values more than $370 \mathrm{~Bq} \mathrm{~kg}^{-1}$ and unity respectively. However the absorbed dose rate at $1 \mathrm{~m}$ above the ash pond was $79.19 \mathrm{n} \mathrm{Gy} \mathrm{h}^{-1}$ (average of 3 plants) higher than the global average value of $55 \mathrm{nGy} \mathrm{h}^{-1}$. The corresponding annual external effective dose is estimated to be $0.68 \mathrm{mSv} \mathrm{y}^{-1}$, which is also more than that $\left(0.46 \mathrm{mSv} \mathrm{y}^{-1}\right)$ in areas of natural background radiation. The 5th percentile, 95 th percentile and mean values for total inhalation risk arising from radionuclides $\left(\mathrm{Ra}^{226}, \mathrm{Th}^{228}, \mathrm{~Pb}^{210}\right.$ and Nat-U) were found to be $3.83 \times 10^{-9}, 6.50 \times 10^{-8}$ and $2.08 \times 10^{-8}$ respectively.
\end{abstract}

\section{INTRODUCTION}

In India, the rapid increase in thermal generation capacity and at the same time a deterioration of the quality of coal with increased ash content resulted in huge quantity of fly ash and bottom ash of varying properties. The coal contains naturally occurring primordial radionuclide thus the use of coal as a heat source for electric power generation will result in the emission of a variety of natural radioactive elements into the environment. The trace elements in coal that are naturally radioactive are uranium $(\mathrm{U})$, thorium (Th), and their decay products, including radium (Ra) and radon (Rn). Thus coal fired power plant is a major contributor towards the Technologically Enhanced Natural Radiation (TENR) as it results in generation of huge amounts of fly ash and bottom ash containing natural radionuclides. Indian coal used in power plants generally has high ash content and is of lower quality (Mathur et. al., 2003). Presently about 110 million tonnes of coal-ash is generated in India from more than 70 thermal power plants (Sarkar et. al., 2005). By the year 2012 this is predicted to increase to 170 million tonnes per annum (Rajamane, 2003). Thus, fly ash and bottom ash are significant sources of exposure to the naturally occurring radionuclides that affect especially the population in the vicinity of industrial areas. In India, the major portion of fly ash produced goes for disposal in ash ponds and landfills; and a small fraction of it is utilized in construction material (taking advantage of its cementitious or binding characteristic) or as soil amendment (mainly because of its high alkalinity). The openly dumped fly ash poses radiation hazard due to the leachability of radionuclides into the ground water stream ultimately contaminating the drinking waters. The disposal and even the utilization in construction work also leads to exposure to radiation doses to the personals in vicinity. Therefore it is necessary to characterize and quantify the natural radioactivity content in fly ash and bottom ash for subsequent evaluation of the associated environmental and biological risks.

The feed coal used in power plants contains various elements, minerals and organic constituents. Upon burn up the elements tend to get enriched in the ashes. Radionuclides which are normally found in the coals get enriched into the ashes after burn up. The concentration of most radioactive elements in 
solid combustion wastes were approximately 5-10 times the concentration in the original coal. Although these elements are less chemically toxic than other coal constituents such as arsenic, selenium, or mercury, they possess concern because of possible risk from radiation. In order to accurately address the radiation risk and to predict the mobility of radioactive elements during the coal fuel-cycle, it is important to determine the concentration, distribution, and form of radioactive elements in coal and fly ash. Thorium in coal is contained mostly in common phosphate minerals such as monazite or apatite. In contrast, uranium is found in both the mineral and organic fractions of coal. Some uranium may be added slowly over geologic time because organic matter can extract dissolved uranium from ground water. During coal combustion most of the uranium, thorium, and their decay products are released from the original coal matrix and are distributed between the gas phase and solid combustion products. The partitioning between gas and solid is controlled by the volatility and chemistry of the individual elements. Virtually 100 percent of the radon gas present in feed coal is transferred to the gas phase and is lost in stack emissions. In contrast, less volatile elements such as thorium, uranium, and the majority of their decay products are almost entirely retained in the solid combustion wastes. Although particle emission controls in power stations may reach high retention efficiency ( $99 \%$ by using electrostatic precipitators), considerable amounts of fine fly ash particles are still emitted from the stack to the atmosphere because of the high rate of coal consumption. The collection efficiencies of pollution control devices are significantly lower for particles less than $10 \mu \mathrm{m}$ in diameter, with the greatest penetration for ultra-fine particles of 0.1-1 $\mu \mathrm{m}$ diameter (Senior et al. 2000, Swaine 2000). Assessment of the radiation exposure from coal burning is critically dependent on the concentration of radioactive elements in coal and in the fly ash that remains after combustion.

The collective doses to the population arise primarily through inhalation of radioactivity during the passage of the cloud containing fly-ash emitted from the stack. Since many of the thermal power plants in India are situated in densely populated areas, the estimation of radiological risk to the neighborhood population may be of significance. In the present study, coal, bottom ash and fly ash samples were collected from three coal-fired power plants in India and subjected to gamma spectrometry analysis for natural radioactivity contents. Radium equivalent activity and external hazard index were calculated for these by-products to assess the radiation hazards arising due to the use of them in the construction of dwellings. Inhalation risk due to the radionuclide release from the thermal power plant stack was estimated using Monte Carlo simulation technique.

\section{MATERIALS AND METHODS}

\subsection{Sample preparation}

Fly ash, bottom ash and coal samples were collected from three different thermal power plants across India. The samples were dried for $24 \mathrm{~h}$ in an air-circulation oven at $110^{\circ} \mathrm{C}$.Samples were further powdered, homogenized and about $100 \mathrm{~g}$ of each sample was filled in plastic containers of $6.5 \mathrm{~cm}$ diameter $\times 7.5 \mathrm{~cm}$ height and sealed to make them airtight for 1month to ascertain establishment of secular equilibrium between ${ }^{226} \mathrm{Ra}$ and ${ }^{228} \mathrm{Th}$ with their daughters and to prevent radon loss. After attainment of secular equilibrium the samples were subjected to gamma-ray spectrometric analysis.

\subsection{Gamma spectrometric analysis}

The gamma-spectrometry system having an $n$-type coaxial HPGe detector (DSG, Germany) shielded with $7.5 \mathrm{~cm}$ thick lead having $50 \%$ relative efficiency and a resolution of $2.1 \mathrm{keV}$ at $1.33 \mathrm{MeV}$ gamma energy of ${ }^{60} \mathrm{Co}$ was used. The gamma spectra acquired for $60,000 \mathrm{~s}$ were analyzed using an $8 \mathrm{~K}$ PC based multichannel analyzer (PHAST, Electronics Division, BARC). 


\subsection{Source term}

The consumption rate of coal for electricity generation is about 12.5 tonnes per MW per day. For a typical 1000 MWe coal based thermal power plant the daily consumption of coal is 12500 tonnes. In the combustion process, $20 \%$ of ash was precipitated as bottom-ash or slag, and $80 \%$ as fly-ash. The 'unified' model of coal-fired power plants (UNSCEAR, 1982) was characterized by a fly-ash retention efficiency of about $97.5 \%$ (2.5\% discharged into the atmosphere by the stacks). The old type of coal-fired power plants (UNSCEAR, 1988) was characterized by a fly-ash retention efficiency of about $90 \%(10 \%$ discharged), while the modern type of power plants was characterized by a fly-ash retention efficiency of about $99.9 \%$ ( $0.1 \%$ discharged). In this study, we have assumed the efficiency of the electrostatic precipitator for discharge control of fly ash is $99 \%$ then only $1 \%$ of the fine ash is released into the ambient air through the stack of the plant. Therefore the emission rate of the fly ash from the stack is work out to be $0.46 \mathrm{Kg} / \mathrm{sec}$. The emission rate of radionuclide was estimated by multiplying the emission rate of fly ash from the stack with the concentration of the respective radionuclide in fly ash.

\subsection{Inhalation dose estimation}

The collective effective dose in one year to the population living around $10 \mathrm{Kms}$ radius in the neighborhood of coal-based thermal power plant were calculated following the method outlined by Papastefanou [1996].

$$
\text { Dose }=\mathrm{C}_{\mathrm{i}} * \mathrm{IR} * \mathrm{DCF}
$$

where $C_{i}\left(B q / \mathrm{m}^{3}\right)$ is the ground level concentration of radionuclides, IR is the inhalation rate $\left(\mathrm{m}^{3} / \mathrm{yr}\right)$, $\mathrm{DCF}$ is the dose conversion factor $(\mathrm{Sv} / \mathrm{Bq})$. The ground level concentrations were obtained from the Gaussian plume model.

\subsection{Risk analysis}

Risk assessment is the process that estimates the likelihood of occurrence of adverse effects to humans and ecological receptors as a result of exposure to hazardous chemical, radiation, and/or biological agents. Quantitative risk characterization involves evaluating exposure estimates against a benchmark of toxicity, such as a cancer slope factor. Risk is calculated by multiplying the carcinogenic slope factor (SF) of the radionuclide by the dose an individual receives. The collective effective doses to the population living in the neighborhood of coal-based thermal power plant were calculated using Gaussian plume dispersion model.

Monte Carlo Analysis is the most widely used probabilistic method in risk assessment. The MCA technique treats any uncertain parameter as random variable that obeys a given probabilistic distribution. This technique is widely used for analyzing probabilistic uncertainty. In MCA computer simulation are use to combine multiple probability distributions associated with the dose and SF depicted in risk equation. Thus we get a probabilistic distribution for the risk.

\section{RESULTS AND DISCUSSION}

Fig. 1 shows the levels of naturally occurring radionuclides in coal, fly ash and bottom ash. It was observed that radionuclides are concentrated more in the ashes due to enrichment after coal burn up. $\mathrm{Th}^{232}$ activity was found to be much higher than other radionuclides while $\mathrm{Pb}^{210}$ showed the minimum activity in fly ash. Only $\mathrm{K}^{40}$ showed lower concentration in the bottom ash than coal due to its presence in the coal in the form of volatile minerals. The results show that in ash produced by the combustion of coal, the concentration of ${ }^{226} \mathrm{Ra}$ is less than that of ${ }^{232} \mathrm{Th}$. Uranium (parent element of radium) is mainly present in the carbonaceous components of sedimentary rocks and accumulates in coal during 


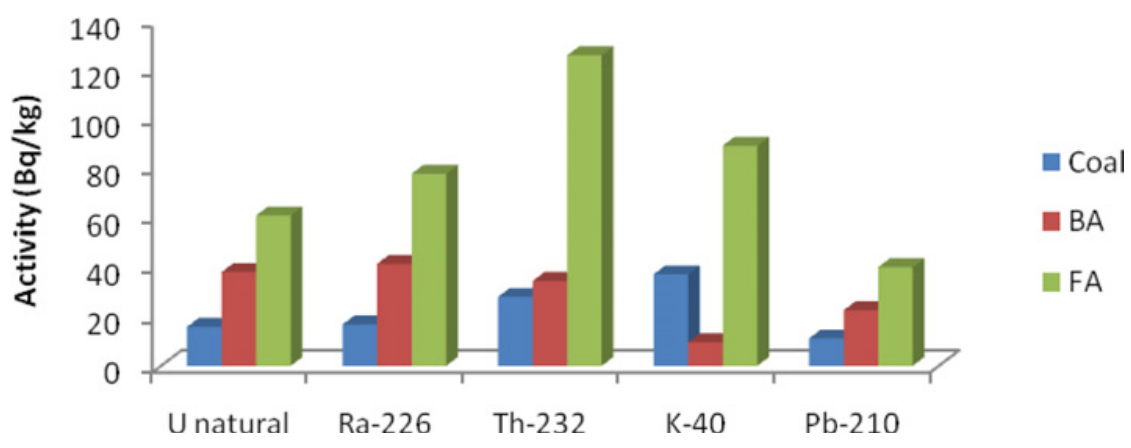

Figure 1. The levels of naturally occurring radionuclides in coal, fly ash and bottom ash.

the process of coalification. It is mainly present in the organic fraction in coal due to sorptive uptake onto the organic fraction during the early stages of peat-accumulation and burial, whereas thorium is present in the inorganic phases.

Due to the organic matter burn-out during the combustion process, the concentration of all the natural radionuclides remaining in the produced ashes, increases depending of course on the physicochemical properties of the specific element. In the case of the nuclides of the uranium series, the three most important nuclides: ${ }^{238} \mathrm{U},{ }^{226} \mathrm{Ra}$ and ${ }^{210} \mathrm{~Pb}$ have different physicochemical properties, resulting in a different behavior inside the power plant. The behavior of uranium during the combustion process depends upon the conditions of the furnace as well as its chemical and physical characteristics of the input fuel. For example, since uranium may exist in the fuel both as uraninite and coffinite, volatile and nonvolatile species may be formed during combustion. ${ }^{226} \mathrm{Ra}$ behaves in a similar way. A portion of ${ }^{226} \mathrm{Ra}$ will reside with the uraninite fraction of its ${ }^{238} \mathrm{U}$ parent, allowing for more mobile species, than the silica associated ${ }^{226} \mathrm{Ra} .{ }^{210} \mathrm{~Pb}$ which is more volatile leaves the boiler with the flue-gas in gaseous form and condenses as the temperature of the flue-gas drops.

It was clearly observed that the radionuclides get accumulated in the ashes after combustion (Fig. 2). As most of the carbonaceous matter in coal oxidizes out during combustion, the radionuclides get concentrated in the remaining mass. Fly ash was observed to be having more enrichment of all the radionuclides than bottom ash. All the values for enrichment factor were above unity for fly ash indicating a net enrichment of the radionuclides. However in the bottom ashes it was observed that $\mathrm{K}^{40}$ had an enrichment factor below unity indicating its removal in the gaseous phase during the combustion process. This could be due to formation of some volatile compound of $\mathrm{K}$ during the combustion process. Similar results were obtained for $\mathrm{K}^{40}$ in a previous study (Mandal et al. 2003) on Indian coal ashes. It was observed that in most of the cases the natural radioactivity levels were 2 to 5 times higher in the ashes than in feed coal. Thus the naturally occurring radionuclides get accumulated in the ashes after the coal burn up leading to higher radioactivities and a posing potential radiological risk to the environment due to the huge amount of ashes generated.

To assess the radiological hazard of fly ash and bottom ash used as building materials, the radium equivalent activity $\left(\mathrm{Ra}_{\mathrm{eq}}\right)$ and external hazard index $\left(\mathrm{H}_{\mathrm{ex}}\right)$ are used in the study. $\mathrm{Ra}_{\mathrm{eq}}$ and $\mathrm{H}_{\mathrm{ex}}$ can be calculated according to (Beretka and Mathew 1985) as

$$
\begin{gathered}
\mathrm{Ra}_{\mathrm{eq}}=A_{\mathrm{Ra}}+1.43 A_{\mathrm{Th}}+0.077 A_{\mathrm{K}} \\
\mathrm{H}_{\mathrm{ex}}=A_{\mathrm{Ra}} / 370+A_{\mathrm{Th}} / 259+A_{\mathrm{K}} / 4810
\end{gathered}
$$

Where $A_{\mathrm{Ra}}, A_{\mathrm{Th}}$ and $A_{\mathrm{K}}$ are the activity concentrations of $\mathrm{Ra}^{226}, \mathrm{Th}^{232}$ and $\mathrm{K}^{40}$ in $\mathrm{Bq} \mathrm{kg}^{-1}$ respectively. $\mathrm{Ra}_{\mathrm{eq}}$ is related to the external $\gamma$-dose and internal dose due to radon and its daughters. The maximum value of $\mathrm{Ra}_{\mathrm{eq}}$ in building materials must be less than $370 \mathrm{~Bq} \mathrm{~kg}^{-1}$ for safe use. $H_{\mathrm{ex}}$ is obtained from the 


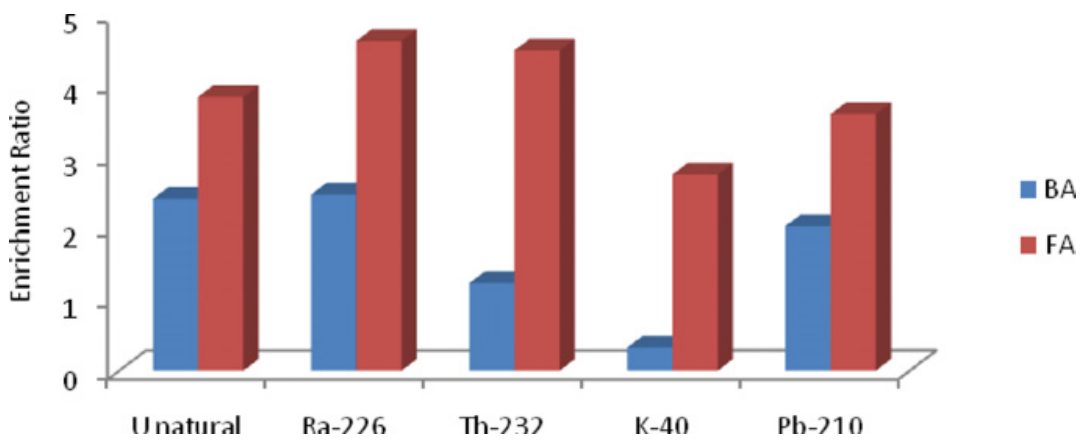

Figure 2. Relative Enrichment of radionuclides in bottom ash and fly ash.

$\mathrm{Ra}_{\mathrm{eq}}$ expression by assuming that its maximum value allowed (equal to unity) corresponds to the upper limit of $\mathrm{Ra}_{\mathrm{eq}}\left(370 \mathrm{~Bq} \mathrm{~kg}^{-1}\right)$. The calculated values of $\mathrm{Ra}_{\mathrm{eq}}$ range from 93.12 to $299.97 \mathrm{~Bq} \mathrm{~kg}^{-1}$ with average of $176.89 \mathrm{~Bq} \mathrm{~kg}^{-1}$ for fly ash, and from 57.02 to $87.66 \mathrm{~Bq} \mathrm{~kg}^{-1}$ with average of $77.14 \mathrm{~Bq} \mathrm{~kg}^{-1}$ for bottom ash. The calculated values of $H_{\mathrm{ex}}$ range from 0.25 to 0.81 with an average of 0.47 for fly ash, and from 0.15 to 0.23 with average of 0.20 for bottom ash.It was observed that the $\mathrm{Ra}_{\mathrm{eq}}$ values and the $H_{\mathrm{ex}}$ values of none of the fly-ash samples were more than the limit of $370 \mathrm{~Bq} \mathrm{~kg}^{-1}$ and unity respectively. An attempt also has been made in the present study to evaluate the gamma dose emitted from the ash pond. Conversion factors to transform specific activities $A_{\mathrm{K}}, A_{\mathrm{Ra}}$ and $A_{\mathrm{Th}}$ of $\mathrm{K}$, Ra and Th respectively, in absorbed dose rate at $1 \mathrm{~m}$ above the ground (in $\mathrm{nGy} \mathrm{h}^{-1}$ by $\mathrm{Bq} \mathrm{kg}^{-1}$ ) are calculated by Monte Carlo method and the values are given by (UNSCEAR 2000)

$$
D\left(n G y h^{-1}\right)=0.0417 A_{\mathrm{K}}+0.462 A_{\mathrm{Ra}}+0.604 A_{\mathrm{Th}}
$$

The results show that the absorbed dose rates range from 42.23 to $132.72 \mathrm{nGy} \mathrm{h}^{-1}$ with mean value of $79.19 \mathrm{nGy} \mathrm{h}^{-1}$. The calculated average dose rates were higher than the global average value $55 \mathrm{nGy} \mathrm{h}^{-1}$ (UNSCEAR 1988).In order to estimate the annual effective dose rates, the conversion coefficient from the absorbed dose in air to the effective dose $\left(0.7 \mathrm{~Sv} \mathrm{~Gy}^{-1}\right)$ and the outdoor occupancy factor $(0.2)$ proposed by (UNSCEAR 2000) were used. The effective dose rate was calculated using the formula,

$$
\text { Effective dose rate }\left(m S v y^{-1}\right)=D\left(n G y h^{-1}\right) \times 8760\left(h y^{-1}\right) \times 0.2 \times 0.7\left(S v G y^{-1}\right) \times 10^{-6}
$$

The calculated effective dose rates in air varied from 0.31 to $1.61 \mathrm{mSv} \mathrm{y}^{-1}$, with an average value of $0.68 \mathrm{mSv} \mathrm{y}^{-1}$. In areas with normal background radiation, the average annual external effective dose rate from the terrestrial radionuclides is $\left(0.46 \mathrm{mSv}^{-1}\right)$ (UNSCEAR 1993) (Yang 2005). The main contributions to radium equivalent activity and external hazard index are ${ }^{232} \mathrm{Th}$ and ${ }^{226} \mathrm{Ra}$ for fly ash and bottom ash, and hence when these are used as additives in building materials, the concentration of natural radionuclides should be monitored. The calculated absorbed dose rate at $1 \mathrm{~m}$ above the ground was $79.19 \mathrm{nGy} \mathrm{h}^{-1}$, which is higher than the global average value of $55 \mathrm{nGy} \mathrm{h}^{-1}$. Also, the average external effective dose rate in the ash pond was $0.68 \mathrm{mSv} \mathrm{y}^{-1}$, which is higher than the average annual external effective dose rate $\left(0.46 \mathrm{mSv} \mathrm{y}^{-1}\right)$ from the terrestrial radionuclides.

\subsection{Risk assessment}

The radioactivity content in fly ash and the emission rate of various radionuclides from the stack of a typical 1000 MWe coal based thermal power plant is given in Table 1. In fly ash maximum concentration was observed for ${ }^{228} \mathrm{Th}$ with a mean value of $125.8 \mathrm{~Bq} / \mathrm{Kg}$ and minimum concentration was observed for ${ }^{210} \mathrm{~Pb}$ with a mean value of $40.5 \mathrm{~Bq} / \mathrm{Kg}$. The emission rate of radionuclide was estimated by multiplying the emission rate of fly ash from the stack with the concentration of the respective radionuclide in 


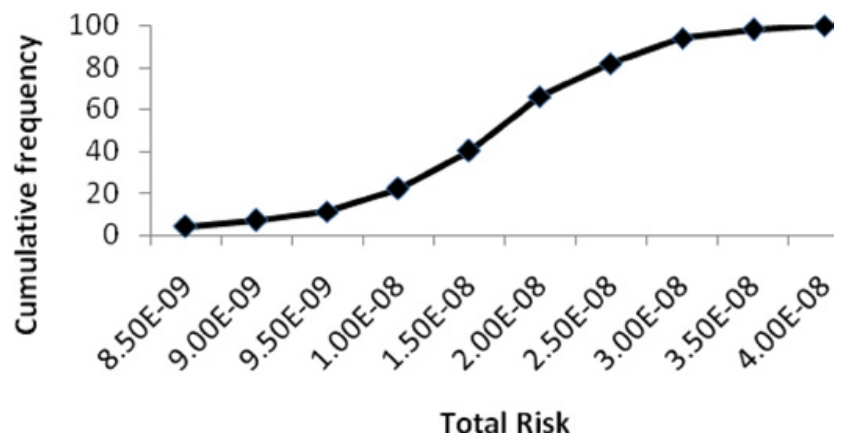

Figure 3. Cumulative frequency distribution of total radiological risk due to inhalation of radionuclide.

Table 1. Radioactivity content in fly ash and emission rate of various radionuclide (mean values are given in parentheses).

\begin{tabular}{|l|c|c|c|}
\hline Radionuclide & $\begin{array}{c}\text { Concentration } \\
(\mathbf{B q} / \mathbf{K g})\end{array}$ & $\begin{array}{c}\text { Emission Rate } \\
(\mathbf{B q} / \mathbf{S e c})\end{array}$ & $\begin{array}{c}\text { Maximum Ground Level } \\
\text { Concentration }\left(\mathbf{m B q} / \mathbf{m}^{3}\right)\end{array}$ \\
\hline${ }^{226} \mathbf{R a}$ & $40.7-151.7(77.7)$ & $18.7-69.8(35.7)$ & 0.11 \\
\hline${ }^{228} \mathbf{T h}$ & $95.1-230.5(125.8)$ & $43.7-106.0(57.9)$ & 0.18 \\
\hline${ }^{210} \mathbf{P b}$ & $25.7-69.6(40.5)$ & $11.8-32.0(18.6)$ & 0.06 \\
\hline${ }^{238} \mathbf{U}$ & $18.8-121.4(60.3)$ & $8.6-55.8(27.7)$ & 0.09 \\
\hline
\end{tabular}

Table 2. Inhalation risk arises due to various radionuclides from MCA method.

\begin{tabular}{|l|c|c|c|}
\hline Radionuclide & $\mathbf{5}^{\text {th }}$ Percentile & $\mathbf{9 5}^{\text {th }}$ Percentile & Mean \\
\hline${ }^{226} \mathrm{Ra}$ & $2.53 \times 10^{-9}$ & $8.64 \times 10^{-9}$ & $5.65 \times 10^{-9}$ \\
\hline${ }^{228} \mathrm{Th}$ & $4.13 \times 10^{-9}$ & $1.41 \times 10^{-8}$ & $9.24 \times 10^{-9}$ \\
\hline${ }^{210} \mathrm{~Pb}$ & $1.44 \times 10^{-9}$ & $4.87 \times 10^{-9}$ & $3.16 \times 10^{-9}$ \\
\hline${ }^{238} \mathrm{U}$ & $2.16 \times 10^{-9}$ & $7.30 \times 10^{-9}$ & $4.74 \times 10^{-9}$ \\
\hline
\end{tabular}

fly ash. The maximum ground level concentrations were calculated from Gaussian Plume Model. The maximum ground level concentrations were observed at a distance of around $2 \mathrm{~km}$ from the stack. The maximum ground level concentration for ${ }^{228} \mathrm{Th}$ was found to be $0.18 \mathrm{mBq} / \mathrm{m}^{3}$ whereas that for ${ }^{210} \mathrm{~Pb}$ was $0.06 \mathrm{mBq} / \mathrm{m}^{3}$.

Monte Carlo simulation technique has been applied to find out the probabilistic inhalation risk. The $5^{\text {th }}$ percentile, $95^{\text {th }}$ percentile and mean values of inhalation risk due to ${ }^{226} \mathrm{Ra},{ }^{228} \mathrm{Th},{ }^{210} \mathrm{~Pb}$ and ${ }^{238} \mathrm{U}$ arises from MCA method was given in Table 2. The result show the inhalation risk arises due to ${ }^{228} \mathrm{Th}$ is significant compared to other radionuclides. Fig. 3 shows the cumulative frequency distribution of total inhalation risk arises from radionuclides $\left({ }^{226} \mathrm{Ra},{ }^{228} \mathrm{Th},{ }^{210} \mathrm{~Pb}\right.$ and $\left.{ }^{238} \mathrm{U}\right)$ using Monte Carlo simulation. The $5^{\text {th }}$ percentile, $95^{\text {th }}$ percentile and mean values for total inhalation risk arises from radionuclide ${ }^{226} \mathrm{Ra},{ }^{228} \mathrm{Th},{ }^{210} \mathrm{~Pb}$ and $\left.{ }^{238} \mathrm{U}\right)$ was found to be $1.03 \times 10^{-8}, 3.51 \times 10^{-8}$ and $2.28 \times 10^{-8}$ respectively. Among the radionuclide considered in this study, ${ }^{228} \mathrm{Th}$ contributed maximum to the total inhalation risk $(41 \%)$ while the minimum contribution was from ${ }^{210} \mathrm{~Pb}(13 \%)$. The higher contribution to the total risk from ${ }^{228} \mathrm{Th}$ can be attributed to its higher concentration in fly ash. 


\section{CONCLUSION}

Ashes produced in thermal power plants may contain high levels of natural radioactivity and constitute a potential health hazard to the power plant personnel, and to the population living in the vicinity, due to fly-ash releases, flyash depositions and fly-ash industrial utilization. The concentration of the radioactive elements in fly ash was found to be higher than that in bottom ash and coal from the three different coal power plants across India. The results showed that the elements are more enriched in fly ash than in bottom ash. The corresponding annual external effective dose due to fly ash was observed to be more than that in areas of natural background radiation. The risk estimated by monte carlo technique to general population residing around thermal power plant shows that Th232 contributes maximum because of its high concentration in fly ash. The data in this study may be helpful in developing environmental pollution abatement methods or technologies for fly ash in various applications.

\section{References}

[1] Beretka, J. and Mathew, P. J. (1985), Natural radioactivity of Australian building materials, industrial wastes and by-products. HealthPhys.48, 87-95.

[2] Mathur R., Chand S., Tezuka T. (2003), Optimal use of coal for the power generation in India, Energy Policy, 31(3):319-31

[3] Papastefanou, C. (1996) Radiological impact from atmospheric releases of ${ }^{226}$ Ra from coal-fired power plants. J. Environmental Radioactivity, 32, 105-114.

[4] Rajamane N.P. (2003), Making concrete 'green' through use of fly ash. Green Business Opportun,, 9(4):23

[5] Sarkar A., Rano R., Mishra K.K, Sinha I.N. (2005), Particle size distribution profile of some Indian fly ash- A comparative study to assess their possible uses; Fuel Process Technol, 86(11):1221-38

[6] Senior C.L., Helble J.J., Sarofim A.F. (2000) Emissions of mercury, trace elements, and fine particles from stationary combustion sources. Fuel Processing Technology, 65-66: 263-288

[7] Swaine D.J. (2000) Why trace elements are important. Fuel Processing Technology, 65-66: 21-33

[8] UNSCEAR (1982) Ionizing radiation: sources and biological effects. United Nation Scientific Committee on the Effects of Atomic Radiation, United Nations, New York.

[9] UNSCEAR (1988), Sources, effects and risk of ionizing radiation. United Nations, New York

[10] UNSCEAR (1993), Exposure from natural sources of radiation, United Nations, New York

[11] UNSCEAR (2000), Sources and effects of ionizing radiation. United Nations Scientific Committee on the Effects of Atomic Radiation, United Nations, New York

[12] Yang, Y. (2005), Radioactivity concentrations in soils of the Xiazhuang granite area, China. Appl. Radiat. Isot., 63, 255-259. 